\title{
A Model of Lean Supplier Management Based on the Lean Production
}

\author{
Yixun Guo and Zhiduan $\mathrm{Xu}^{2}$ \\ ${ }^{1}$ Department of Statistics, College of Economics, Xiamen University, Xiamen 361005, \\ Fujian, P.R. China xm-gyx@263.net \\ ${ }^{2}$ MBA Education Center, School of Management, Xiamen University, Xiamen 361005, \\ Fujian, P.R.China zhiduanx@xmu.edu.cn
}

\begin{abstract}
In this paper, we present a model of lean supplier management between an OEM and its suppliers for the objectives of eliminating wastes, reducing cost and improvement continuously based on the lean production. This model includes supplier selection and categorization, supplier improvement, supplier certification and supplier evaluation. First, the supplier selection process and some basic principals about selection criteria are developed, and all suppliers will be categorized so that different management measures can be used effectively. Then, we design the Supplier Quality Assessment process that focus on a comprehensive, continuous improvement of supplier's quality system and processes utilizing benchmarked and time-proven techniques. Finally, the index system of performance evaluation on lean suppliers is given in order to understand what performances a supplier has achieved over the past period, to identify chances that a supplier will be improved, and to provide evidences for re-certification of suppliers during next period.
\end{abstract}

Keywords: Lean production, Supplier relationship management, Lean supplier management, Operations management, Quality assurance, Performance evaluation

\section{INTRODUCTION}

With uncertainty in competitive business environment, OEMs placed in the middle of supply chain are facing challenges about product variety, lower cost and better quality. Lean thinking which aims eliminating wastes, reducing cost and improvement continuously provides a strategic guiding tool for OEMs so as to gain competitive advantages [1]. Therefore, the lean production approach pioneered by Toyota is being adopted by lots of OEMs, especially in the electronic industry, such as DELL and KODAK. The term 'lean' embodies a system that uses less of all inputs to create outputs similar to the mass production system but offering an increased choice to the end customers [2]. For full effectiveness, the lean production system must be extended down through the supply chain. The need for minimal inventory for cost and quality reasons and early detection of defects requires a kanban supply arrangement [3]. Suppliers need to deliver frequently, in small quantities, as required to the point of use with total quality guaranteed eliminating the need for incoming inspection. Suppliers are also involved in the design of components with assemblers, organizing

Please use the following format when citing this chapter:

Guo, Y., Xu, 7... 2007, in IFIP International Federation for Information Processing, Volume 254. Research and Practical Issues of Enterprise Information Systems II Volume 1, eds. I. Xu, Tjoa A., Chaudhry S. (Boston: Springer), pp. $717-$ 726. 
their supply base into a tired hierarchical structure. It means that an OEM adopting lean production approach and its key suppliers (called lean suppliers) should be locked together in long term. Suppliers are not only the most direct outer element which influences manufacturers' production and business, but also the key factor which guarantee the quality, price, delivery and service of the product. This paper focuses on an electronic manufacturer and its suppliers from an OEM's perspective. For the sake of convenience, an electronic manufacturer will be referred to as 'the Company' throughout the paper. In this paper, we will present a framework for lean supplier management based on the lean production. Then, we will focus on how to select lean suppliers, control quality of lean suppliers, and evaluate performances of lean suppliers.

\section{A FRAMEWORK FOR LEAN SUPPLIER MANAGEMENT}

Lean production system can not be realized without a lean supply. A lean supply arrangement should provide a flow of goods, services and technology from suppliers to the Company (with the associated flows of information and other communications in both directions) without waste [4]. The nucleus of a lean supply is lean supplier management. Figure 1 shows a framework for lean supplier management.

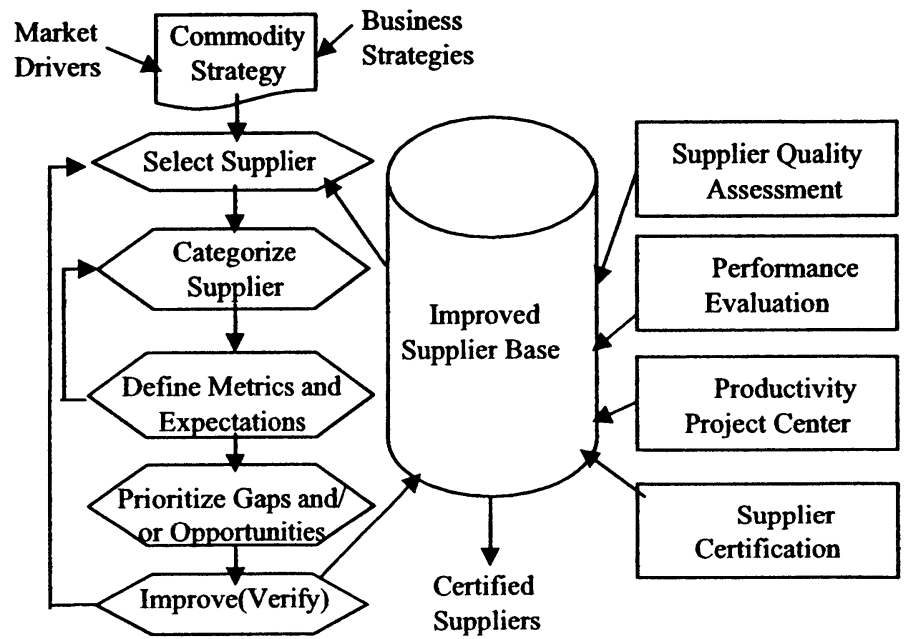

Figure 1. The Framework for Lean Supplier Management

The framework covers all aspects of lean supplier management including business strategy, supplier categorization, supplier improvement, supplier certification and supplier evaluation. The purpose of the framework is to manage the Company's portfolio of suppliers, utilizing Total Quality Management techniques, so that increased productivity results from the optimal deployment of resources. Based on this framework, supplier management activities may be divided into two parts: the 
first part is aimed at selecting a new supplier; the second part is to manage those suppliers who have been in the Company's supplier base. If a new supplier is selected and verified, it will enter into the Company's supplier base and then can be managed by the second part activities. The first part will be described in Section 3 . The second part includes the followings:

(1) Supplier quality assessment: This is a comprehensive, on-site evaluation of supplier's quality system and processes. Utilizing benchmarked and time-proven techniques, a supplier is assessed for its ability to meet the Company's quality and cycle time expectations. This aggressive, evidence-based approach is used to identify the supplier's current capabilities, focus on continuous improvement and ability to meet ever-increasing demands. Section 4 will give the details.

(2) Performance evaluation: Performance evaluation is to examine those suppliers in the Company's supplier base over past period by way of some indexes such as quality, delivery, cost, responsiveness \& support and innovation. So the Company may know on which level its each supplier will be placed and then should take some corresponding effective measures to improve. Section 5 will describe the specific evaluating methods.

(3) Productivity project center: Productivity here refers to the ability to "cash" quality and/or reliability improvements. It is expected that suppliers who are in the Company's top $80 \%$ spend will provide a number of productivity ideas to the Company each year. In fact, the Company can establish a supplier on-line idea database in which a supplier is encouraged to connect to and put forwards proposals for productivity. Productivity project center is a process to manage these proposals and track information about the adoption of these proposals. The information is very helpful for the specific commodity manager to make sourcing decisions.

(4) Supplier certification: Certification is the designation/status earned by a supplier who consistently demonstrates excellent levels of quality, productivity, and delivery performance. By means of certification, suppliers may benefit from systematic improvements which potentially increase the supplier's profit margin, first consideration for new business and visible recognition from the Company; the Company may benefit from confidence in the supplier's quality systems to consistently produce defect-free and reliable products/services, products/services are received when needed, and continual (year- over-year) productivity improvements. If a degradation of supplier performance occurs at any time, and causes significantly negative impact on the Company operations, the supplier's certification status will be withdrawn. Although certification is not the prime objective of supplier management, it is the Company's vision to have all of key suppliers (top $90 \%$ spend and critical) become certified. In this way, the Company may build a competitive and world-class supply base and ensure optimal deployment of valuable resources.

In this framework, the improved supplier base is dynamic. Maybe new selected and verified suppliers are input. Meanwhile, a supplier's data will be upgraded based on its performance over past period. Those suppliers who don't pass the certification will be kicked out. 


\section{SELECTION AND CATEGORIZATION OF LEAN SUPPLIERS}

Lean supplier management starts from the selection of lean suppliers. According to the characteristics of the lean production, key lean suppliers may play significant roles as co-producers. So the selection of lean suppliers is one of critical success factors for the lean production [5]. In this section, the supplier selection process will be described first, then some basic principals about criteria for lean suppliers have to be discussed, and finally all suppliers will be categorized so that different management measures can be used effectively.

\subsection{The Supplier Selection Process}

Supplier Selection is the process of developing criteria and representative importance weightings by which potential suppliers will be evaluated. The best candidates proceed to the negotiation phase for final determination of who will be chosen to fulfill the strategy. Because of the risk of bias, the supplier selection process is summarized below:

(1) Develop criteria based on market and business needs

(2) Weight the criteria based on importance

(3) Identify all potential suppliers

(4) Reduce the number of suppliers to be considered based on required criteria

(5) Visit Supplier and perform Supplier Quality Assessment to further evaluate

(6) Perform final evaluation and rating of the supplier "finalists"

(7) Negotiate and Select "best" supplier or combination of suppliers

(8) Feedback learning to selected supplier(s) for subsequent quality planning

\subsection{The Basic Principals of Developing Criteria for Lean Suppliers}

It is important to emphasize on lean supply seamlessly between the Company and suppliers. So the selection criteria for lean suppliers are usually focused on quality, cost, cycle time and delivery. It depends on the Company's specific situation. The selection criteria is not a 'one size fits all'. But there are some basic principals to develop the selection criteria. In order to meet the need for lean production, the potential suppliers may be examined through the followings: quality assurance system; flexibility of production; responsiveness to changeable plans; capability for managing inventories; flexibility of delivery; reputations.

In a word, a strategy should have been developed for sourcing that has taken into consideration particular market drivers and business strategies. Suppliers are selected based on this strategy. Then suppliers need to be categorized based on short-term and long-term needs. The categorization determines the extent and responsibility for the metrics definition/expectations, gaps/opportunities, and improvement phases. 


\subsection{Supplier Categorization}

Categorization or grouping is a way to manage a large base of suppliers, in a way that maximizes results in each category by minimizing both the amount and intensity of resources expended in each category. Categorization will determine the nature and level of resources utilized and what expectations are placed on the supplier. Guidelines for categorizing suppliers include, but are not limited to: Product/Industry growth (declining versus increasing); Market drivers (price versus technology); Length of desired involvement (short-term versus long-term); Criticality (low versus high); Requirements (standard versus custom); Types of projects with suppliers (tactical versus strategic); Switching costs (low versus high).

The above is to be used as a guideline only. The business needs and value of opportunities will determine the ultimate decision of the supplier's category. Usually, there are four types of suppliers as follows: Type I, Low value/low risk and convenience sources; Type II, High value/low risk and multiple Sources; TypeIII, Low value/high risk or sole sources; Type IV, High value/high risk and/or single sources[4].

Based on these four types of suppliers, we divide suppliers into four categories as follows:

(1) Strategic suppliers: Suppliers are designated as "Strategic" when the Company desires a longer-term relationship, possibly due to product or service co-development opportunities. A supplier in this category is a Type I supplier.

(2) Key item suppliers: Key Item suppliers are those who require involvement with the Company due to the criticality of the product or service they provide. This involvement is usually a medium-term effort in order to receive a level of assurance prior to a "ship to use" status. This is most likely Type II suppliers, and possibly some I's and III's.

(3) Manage-By-Exception suppliers: Whether caused by a change in the Company's processes, or a problem or change caused by the Supplier, it may become necessary to engage in a short-term project with the supplier. This supplier could come from any of the four types.

(4) Approved suppliers: Any supplier who has not been identified as belonging to one of the other categories (Strategic, Key Item, and Manage-By-Exception) but in the Company's supply base is in the approved category. It is in the Company's best interests to reduce the key supply base $(90 \%$ spend) to a manageable number of suppliers. Being competitive within their industry is an expectation common to all approved suppliers. The Company's resources will be minimally utilized for this category. If additional resources are necessary beyond general communication or the setting of expectations, this is an indication that the supplier may not be categorized properly or that the supplier should be removed from the base.

Based on the category chosen for the supplier, subsequent efforts will be different. The Table 1 below provides a summarization. 
Table 1. Different Efforts on the Supplier Based on the Category

\begin{tabular}{|c|c|c|c|}
\hline Suppliers & $\begin{array}{l}\text { Define Metrics and } \\
\text { Expectations }\end{array}$ & $\begin{array}{l}\text { Identify Gaps / } \\
\text { Opportunities }\end{array}$ & Improve (verify) \\
\hline Strategic & $\begin{array}{l}\text { Consider } \\
\text { certification criteria } \\
\text { plus client needs. }\end{array}$ & $\begin{array}{l}\text { Jointly identify and } \\
\text { prioritize. }\end{array}$ & $\begin{array}{l}\text { Close gaps and } \\
\text { show results jointly. } \\
\text { Re-categorize supplier } \\
\text { if/when needed. }\end{array}$ \\
\hline Key Item & Client needs. & $\begin{array}{l}\text { Use some specific } \\
\text { standards of the Company } \\
\text { to develop plan. }\end{array}$ & $\begin{array}{l}\text { Work quality plan } \\
\text { to completion then re- } \\
\text { categorize supplier. }\end{array}$ \\
\hline $\begin{array}{l}\text { Manage- } \\
\text { by- } \\
\text { Exception }\end{array}$ & Specific to problem. & $\begin{array}{cc}\text { Establish } & \text { target } \\
\text { expectations. } & \end{array}$ & \begin{tabular}{l}
\multicolumn{2}{c}{ Report progress } \\
until gap closed. \\
Maintain rata \\
monitoring system and \\
move back to \\
"approved."
\end{tabular} \\
\hline Approved & $\begin{array}{l}\text { Communicate } \\
\text { Certification criteria, } \\
\text { generic expectations. }\end{array}$ & Supplier responsible. & $\begin{array}{l}\text { Supplier } \\
\text { responsible; provides } \\
\text { data to Commodity } \\
\text { Manager, } \\
\text { requested. }\end{array}$ \\
\hline $\begin{array}{l}\text { Not yet } \\
\text { selected }\end{array}$ & $\begin{array}{l}\text { Supplier quality } \\
\text { assessment and other } \\
\text { needed information. }\end{array}$ & $\begin{array}{l}\text { Select best supplier } \\
\text { based on assessment } \\
\text { results and information } \\
\text { obtained. }\end{array}$ & $\begin{array}{l}\text { Categorize supplier } \\
\text { and continue as noted. }\end{array}$ \\
\hline
\end{tabular}

\section{Quality Systems and Assessments of Lean Suppliers}

\subsection{Quality Systems}

It is generally believed that quality does not happen by chance, especially over the long term. As the Company desires to have higher levels of assurance with regards to supplier quality, reliability, serviceability, and delivery, additional attention is placed on the supplier's quality system. Therefore, the following expectations are placed on a supplier:

(1) Have a documented quality system.

(2) Use process controls and stress defect prevention rather than defect detection.

(3) Maintain records that support lot traceability.

(4) Maintain records that support reliability and serviceability performance metrics.

(5) Characterize all processes.

(6) Achieve designs and processes that result in $\mathrm{Cp}>2$ and $\mathrm{Cpk}>1.5$.

(7) Strive for continual improvement in quality and reliability in all facets of operations. 
The following Table 2 may help to distinguish where quality tools may be best utilized. It is meant to be used a guideline only.

Table 2. Quality Tools Matrix

\begin{tabular}{|c|c|c|c|}
\hline Category & Define Metrics & Identify Gaps & Improve (verify) \\
\hline Strategic & $\begin{array}{l}\text { Concurrent product / process } \\
\text { design; Voice of the Customer } \\
\text { (VOC); Quality Function } \\
\text { Deployment (QFD); Cycle } \\
\text { time methodology; Defect } \\
\text { measurement / } 6 \text { sigma; Failure } \\
\text { Modes and Effects and } \\
\text { Criticality Analysis (FMECA)/ } \\
\text { Failure Modes and Effects } \\
\text { Analysis (FMEA); Reliability } \\
\text { methods; Process capability; } \\
\text { Data interpretation / } \\
\text { presentation; Design of } \\
\text { Experiments (DOE);Decision } \\
\text { and risk analysis }\end{array}$ & $\begin{array}{l}\text { Value Analysis and } \\
\text { Value Engineering } \\
\text { (VA/VE); Pugh } \\
\text { Concept Selection; } \\
\text { Process Mapping; } \\
\text { Process capability; } \\
\text { Descriptive } \\
\text { statistics; } \\
\text { Graphical } \\
\text { techniques }\end{array}$ & $\begin{array}{l}\text { Management-By- } \\
\text { Fact(MBF); } \\
\text { Concurrent product / } \\
\text { process design; Design } \\
\text { for "x" (DFX); } \\
\text { Mistake proofing / } \\
\text { fail-safing; Seven } \\
\text { basic quality tools; } \\
\text { Data interpretation / } \\
\text { presentation }\end{array}$ \\
\hline Key Item & $\begin{array}{l}\text { VOC; QFD; Defect } \\
\text { measurement / 6 sigma; Item } \\
\text { Quality Process; FMECA } \\
\text { /FMEA; Reliability methods; } \\
\text { Process capability; Data } \\
\text { interpretation / presentation; } \\
\text { DOE; Decision \& risk analysis }\end{array}$ & $\begin{array}{l}\text { VA/VE; Pugh } \\
\text { Concept Selection; } \\
\text { Process Mapping; } \\
\text { Cycle time } \\
\text { methodology; } \\
\text { Tolerating; Item } \\
\text { Quality Process; } \\
\text { Process capability; } \\
\text { Descriptive } \\
\text { statistics; } \\
\text { Graphical } \\
\text { techniques } \\
\end{array}$ & $\begin{array}{l}\text { MBF; Design for " } \mathrm{x} " \\
\text { (DFX); Item Quality } \\
\text { Process; Mistake } \\
\text { proofing / fail-safing; } \\
\text { Seven basic quality } \\
\text { tools; Data } \\
\text { interpretation / } \\
\text { presentation }\end{array}$ \\
\hline $\begin{array}{l}\text { Manage- } \\
\text { By- } \\
\text { Exception }\end{array}$ & $\begin{array}{l}\text { Defect measurement / } 6 \text { sigma; } \\
\text { FMECA /FMEA; Reliability } \\
\text { methods; Seven basic tools; } \\
\text { Data interpretation / } \\
\text { presentation; Decision \& risk } \\
\text { analysis }\end{array}$ & $\begin{array}{l}\text { Process Mapping; } \\
\text { Graphical } \\
\text { techniques }\end{array}$ & $\begin{array}{l}\text { MBF; Design for " } \mathrm{x} \text { " } \\
\text { (DFX); Cycle time } \\
\text { methodology; Mistake } \\
\text { proofing / fail-safing; } \\
\text { Seven basic quality } \\
\text { tools; Data } \\
\text { interpretation / } \\
\text { presentation; } \\
\text { Statistical software }\end{array}$ \\
\hline $\begin{array}{l}80 \% \\
\text { Spend } \\
\text { (subset of } \\
\text { Approved) }\end{array}$ & $\begin{array}{l}\text { Defect measurement / } 6 \text { sigma; } \\
\text { Data interpretation / } \\
\text { presentation }\end{array}$ & $\begin{array}{l}\text { Process Mapping; } \\
\text { Graphical } \\
\text { techniques; } \\
\text { Benchmarking }\end{array}$ & $\begin{array}{l}7 \text { basic quality tools; } \\
\text { Data interpretation / } \\
\text { presentation; Strategic } \\
\text { Cost Analysis }\end{array}$ \\
\hline $\begin{array}{l}100 \% \\
\text { Spend( } \\
\text { Approved) }\end{array}$ & $\begin{array}{l}\text { Defect measurement / } 6 \text { sigma; } \\
\text { Data interpretation / } \\
\text { presentation }\end{array}$ & $\begin{array}{l}\text { Graphical } \\
\text { techniques }\end{array}$ & $\begin{array}{l}7 \text { basic quality tools; } \\
\text { Data interpretation / } \\
\text { presentation }\end{array}$ \\
\hline
\end{tabular}




\subsection{The Supplier Quality Assessment}

The Supplier Quality Assessment process is a comprehensive, on-site evaluation of supplier's quality system and processes. Utilizing benchmarked and time-proven techniques, a supplier is assessed for its ability to meet the Company's quality and cycle time expectations. This aggressive, evidence-based approach is used to identify the supplier's current capabilities, focus on continuous improvement and ability to meet ever-increasing demands. Elements of the assessment include:

(1) Management of the quality system and business

Organization, commitment, measurement and reporting, training, cost analysis, continuous improvement activities and teams, and customer feedback

(2) Process capability

Understanding of customer requirements, specification review, order entry, use of process flow maps, capability studies, and identification of key process parameters that affect ability to meet customer requirements, and process control.

(3) Change control

Customer notification of supplier caused changes, audit trails, and revision management.

(4) Process control

Training, data collection and usage, ongoing control criteria, use of statistical and problem-solving tools, and process evaluation and improvement.

(5) Control of purchased and non-conforming materials

How data is defined, tracked, analyzed, and used to improve the purchasing, design, contract, and production processes.

(6) Corrective and preventive action

Analysis of problems, implementation of solutions to prevent recurrence of problems, usage of data to identify trends and prevent potential problems, internal auditing, and verification of effectiveness of solutions.

Although the assessment utilizes several ISO900X concepts, it goes beyond ISO documentation evaluation, into the effectiveness of the processes themselves. ISO registration does not necessarily correlate to a successful Supplier Quality Assessment result.

\section{PERFORMANCE EVALUATION ON LEAN SUPPLIERS}

The purposes of performance evaluation on lean suppliers are to understand what performances a supplier has achieved over the past period (a year usually), to identify chances that a supplier will be improved, and to provide evidences for re-certification of suppliers during next period. Obviously, the objectives of performance evaluation are those who have been approved in the Company's supplier base and are active over the past period. Based on the lean production, the index system of performance evaluation on lean suppliers may be adopted as shown in Figure.2.

In Figure.2, the second level has eighteen indexes in which each index is evaluated a score between 0 and 5; the first level has five indexes, i.e. quality, delivery, cost, responsiveness \& support and innovation, where the score of each index is equal to its 
weight (shown in Figure.2) multiply the average score of its second level indexes. All scores of the first level indexes are summed to be the final score of a supplier. The full score is 100 . In general, the evaluators may be those who contact with suppliers daily inside the Company, usually from the plan department, the purchasing department, the product development department, the quality management department, the production department and etc.

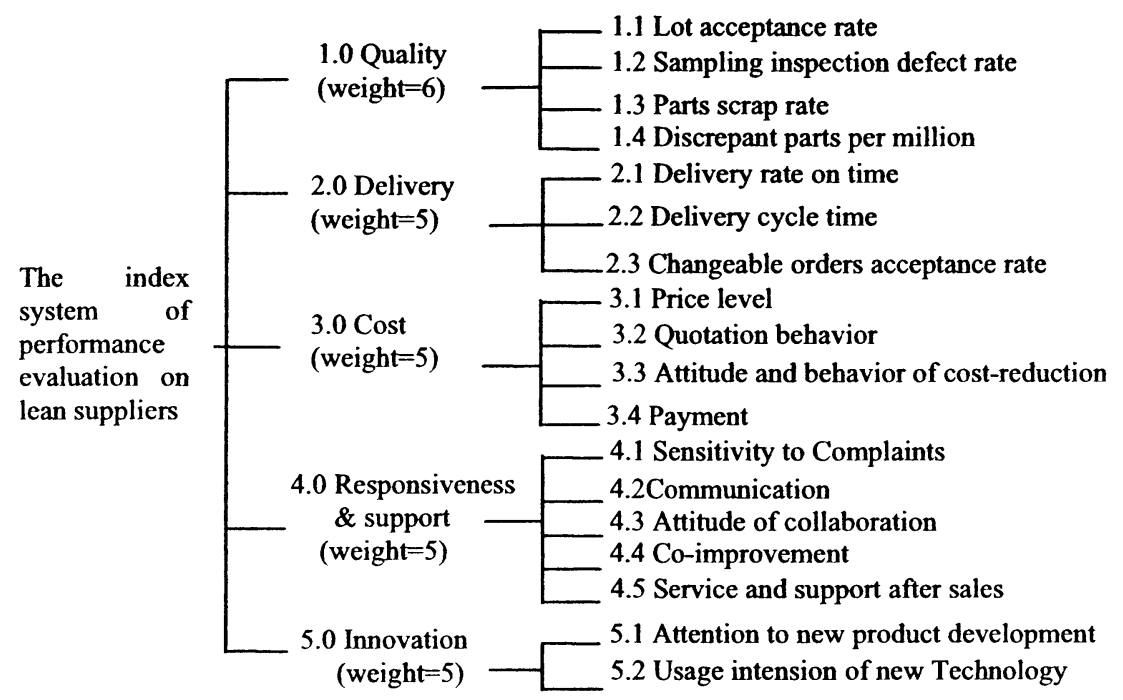

Figure 2. The Index System of Performance Evaluation on Lean Suppliers

\section{CONCLUSIONS}

Modern enterprises have begun to realize the suppliers' great influence on them and regard the establishment and development of the cooperation relation with suppliers as their business strategy. Lean production needs lean supply that puts forward much stricter requirements on suppliers. No doubt, lean supplier management has become one of the key success factors for an OEM. In this paper, we describe some practices on lean supplier management such as supplier selection and categorization, quality control and assessment, performance evaluation. Of course, lean supplier management covers more than these. The purpose of this paper is just to provide some useful tools and methods for those who want to improve their supplier management based on the lean production. 


\section{REFERENCES}

1. M.A. Lewis, Lean Production and Sustainable Competitive Advantage, International, Journal of Production and Operations Management. Volume 28, Number 8, pp.959-978, (2000).

2. J.P. Womack and D. T. Jones, From Lean Production to the Lean Enterprise, Harvard Business Review. Volume 75, pp.93-103, (1994).

3. M. Ronan, Lean Supply: the Design and Cost Reduction Dimensions, European Journal of Purchasing and Supply Management. Volume 7, pp.227-242, (2001).

4. R. Lamming, Squaring Lean Supply with Supply Chain Management, International Journal of Operations and Production Management. Volume 16, Number 2, pp.183-196, (1996).

5. S. New and J. Ramsay, A Critical Appraisal of Aspects of the Lean Chain Approach, European Journal of Purchasing and Supply Management. Volume 2, Number 2, pp.93102, (1997). 